\title{
A situational analysis of pharmacovigilance plans in the Global Fund Malaria and U.S. President's Malaria Initiative proposals
}

\author{
Andy Stergachis ${ }^{*+1,2}$, Rebecca JK Bartlein ${ }^{+1}$, Alexander Dodoo 3 , Jude Nwokike ${ }^{4}$ and S Patrick Kachur ${ }^{5}$
}

\begin{abstract}
Background: Pharmacovigilance programmes can monitor and help ensure the safe use of medicines that are critical to the success of global public health programmes. The widespread deployment of artemisinin-based combination therapy (ACT) by national malaria control programmes as part of the overall Global Malaria Action Plan for malaria control to elimination and eradication makes ACT an excellent candidate for pharmacovigilance activities. In 2008, The Roll Back Malaria partnership issued guidelines for inclusion of pharmacovigilance in Global Fund and other related proposals. In light of this recommendation and the rapid scale-up of ACT worldwide, an analysis of Global Fund Round 8 proposals and the President's Malaria Initiative (PMI) 2009 Malaria Operational Plans was conducted to assess if and how pharmacovigilance has been incorporated into countries' national malaria plans and donor budget requests.

Methods: The Global Fund - Malaria Round 8 proposals for the 26 countries and the PMI Malaria Operational Plans (MOPs) for fiscal year 2009 for the 15 countries that were approved and received funding from either the Global Fund Malaria Round 8 or PMI were accessed through the programme websites. The analysis consisted of conducting word counts and key word in context analyses of each proposal and plan.

Results: Twelve out of 26 (46\%) of the Global Fund proposals mentioned that established pharmacovigilance systems were present in their countries. Four of the fifteen PMI MOPs (27\%) mentioned that established pharmacovigilance systems were present in their countries. Only seven of the 26 (27\%) Global Fund proposals included a request for funding for new or current pharmacovigilance activities. Seven of 15 (47\%) MOPs included a request for funding for pharmacovigilance activities.

Conclusions: There were relatively few requests for funding for pharmacovigilance activities, demonstrating a lack of emphasis placed on pharmacovigilance systems in recipient countries. The findings stress the need for more active direction to strengthen active surveillance and passive adverse event reporting systems to augment the issuance of guidance documents.
\end{abstract}

\section{Background}

Malaria is a major global public health concern with over 250 million cases annually resulting in close to one million deaths, mostly among young children in sub-Saharan Africa [1]. This devastating disease can be prevented and managed through the proper use of anti-malarial medicines, long-lasting insecticide-treated nets, and indoor residual spraying. The evidence-base for each of these

\footnotetext{
* Correspondence: stergach@uw.edu

1 Department of Global Health, School of Public Health, Box 357236 University of Washington, Seattle, WA 98195, USA

+ Contributed equally

Full list of author information is available at the end of the article
}

strategies has grown in recent years and has led to the adoption of country policies and guidelines intended to avert malaria cases and save lives [2]. Malaria control efforts have been strengthened by increased funding from numerous donor groups and agencies. Among the largest donor organizations in combating malaria are The Global Fund to Fight AIDS, Tuberculosis and Malaria (Global Fund) and the United States' President's Malaria Initiative (PMI). Increases in donor support combined with renewed drug development efforts and successes in scale-up programmes have resulted in greater access to

(c) 2010 Stergachis et al; licensee BioMed Central Ltd. This is an Open Access article distributed under the terms of the Creative ComBFoMed Central mons Attribution License (http://creativecommons.org/licenses/by/2.0), which permits unrestricted use, distribution, and reproduction in any medium, provided the original work is properly cited. 
newer treatments for malaria, such as artemisinin-based combination therapy (ACT).

Introducing newer medicines with limited real-world safety data, such as ACT, into poorly funded health care systems combined with large scale-up access programmes make it imperative to monitor their use and safety. Without efforts to assure that accurate and timely safety information is generated and used, significant resources could be wasted, poor quality products could cause harm, and suboptimal use of medicines could adversely affect patient outcomes and fall short of the goal of improved access to quality, efficacious medicines at affordable cost [3-5]. Pharmacovigilance is the science and activities relating to the detection, evaluation, understanding and prevention of adverse reactions to medicines or any other medicine-related problems and is critical for evaluating and characterizing a drug's riskbenefit profile after being released onto the market [6]. Pharmacovigilance is important in the resource-constrained settings because patients may present different susceptibility profiles for adverse events due to genetic, nutritional, co-morbidity, and other differences and many resource-limited countries lack some or all of the World Health Organization's (WHO) basic elements of a pharmacovigilance system $[7,8]$. The conduct of pharmacovigilance includes passive reporting of adverse drug events, focused active surveillance studies, the use of confirmatory pharmacoepidemiologic studies, and risk mitigation and risk communication strategies [9]. One of the recommended active surveillance approaches to evaluate systematically the postmarketing safety of medicines used during pregnancy is the use of pregnancy exposure registries, a strategy for pharmacovigilance recommended for products, such as ACT, likely to be used during pregnancy [10-13].

Since the greatest burden of malaria falls upon low- and middle-income countries with inadequate pharmacovigilance systems in place, it is imperative that programmes to support malaria case management also include provisions for pharmacovigilance surveillance. In recognition of this need, the Roll Back Malaria partnership (RBM) issued guidance to countries applying for malaria funding in mid-2008 for the conduct and use of pharmacovigilance within donor-supported programmes. RBM issued recommendations and a template that strongly encouraged all countries to include pharmacovigilance in their national malaria plans as well as to budget for a pharmacovigilance component in any Global Fund or other grant proposal for rapid scale-up of use of ACT [14,15]. In light of these recommendations to increase the attention and funding for pharmacovigilance specific to ACT, Global Fund Round 8 proposals that were due in mid-2008 were analysed. In addition, PMI 2009 Malaria Operational Plans that were due prior to October 2008 were examined to assess if and how pharmacovigilance has been incorporated into countries' national malaria plans and requests made of this major donor.

\section{Methods}

The Global Fund - Malaria Round 82008 proposals for the 26 countries and the PMI Malaria Operational Plans (MOPs) for fiscal year 2009 for the 15 countries were accessed from the respective programmes' websites in their entirety (Table 1). All of these proposals were approved and received funding from either the Global Fund - Malaria Round 8 or PMI. Word count and Key Word in Context (KWIC) analyses were conducted on all sections that could contain pharmacovigilance information [16]. In order to evaluate how effectively the RBM guidance was incorporated into the Global Fund proposals, they were examined as well as the PMI MOPs for all specific references to pharmacovigilance-related activities, including budget allocations and evidence of integration of pharmacovigilance into national malaria programmes. Specific search terms were: pharmacovigilance, drug safety, artemisinin, ACT, active surveillance, passive surveillance, post-market surveillance, and pregnancy registry. Both structural and thematic coding was conducted [17] by quantifying the pharmacovigilance references and analysing them for consistency in their definitions of aspects of pharmacovigilance systems such as passive surveillance, active surveillance, and pregnancy registries. Additionally, content analysis of proposals was performed by hand and with ATLAS.ti@ software [18].

\section{Results}

Twelve out of 26 (46\%) Global Fund proposals mentioned that established pharmacovigilance systems were present in their countries (Table 2). When prompted by section 4.10.4 in the Global Fund Round 8 proposal form to cite the integration of current pharmacovigilance activities or to cite future plans, only eight out of 26 countries did so (31\%). None of the Global Fund proposals mentioned having or planning to develop a pregnancy registry in their country. Four out of fifteen PMI MOPs (27\%) mentioned that established pharmacovigilance systems were present in their countries (Table 2). Only one MOP, from Uganda, mentioned having or planning to develop a pregnancy registry. Four countries had both a MOP and a Global Fund proposal allowing for comparisons between proposals: Ghana, Ethiopia, Rwanda, and Tanzania. Table 3 illustrates inconsistencies in the information submitted by these countries for the PMI MOPs for 2009 and GF Round 8 Malaria proposals. Ghana and Ethiopia, for example, mentioned pharmacovigilance in their Global Fund proposals, but not in the PMI MOP. Tanzania referred to using previous PMI funds to strengthen pharmacovigilance systems, but did not describe pharma- 
Table 1: Countries included in analyses by type of proposal

\begin{tabular}{|c|c|}
\hline Global Fund Round 8 Proposal & Country \\
\hline http://www.theglobalfund.org/grantdocuments/8AFGM 16140 full.pdf & Afghanistan \\
\hline http://www.theglobalfund.org/grantdocuments/8BOLM 16270 full.pdf & Bolivia \\
\hline http://www.theglobalfund.org/grantdocuments/8BRAM 16320 full.pdf & Brazil \\
\hline http://www.theglobalfund.org/grantdocuments/8BURM 16360 full.pdf & Burkina Faso \\
\hline http://www.theglobalfund.org/grantdocuments/8CAFM 16450 full.pdf & Central African Republic \\
\hline http://www.theglobalfund.org/grantdocuments/8COLM 16520 full.pdf & Colombia \\
\hline http://www.theglobalfund.org/grantdocuments/8COMM 16550 full.pdf & Comoros \\
\hline http://www.theglobalfund.org/grantdocuments/8COGM 16600 full.pdf & Congo Republic \\
\hline http://www.theglobalfund.org/grantdocuments/8ZARM 16580 full.pdf & DR of Congo \\
\hline http://www.theglobalfund.org/grantdocuments/8CIVM 16620 full.pdf & Côte d'Ivoire \\
\hline http://www.theglobalfund.org/grantdocuments/8ECUM 16680 full.pdf & Ecuador \\
\hline http://www.theglobalfund.org/grantdocuments/8ETHM 16720 full.pdf & Ethiopia \\
\hline http://www.theglobalfund.org/grantdocuments/8GHNM 1678 0 full.pdf & Ghana \\
\hline http://www.theglobalfund.org/grantdocuments/8HTIM 16850 full.pdf & Haiti \\
\hline http://www.theglobalfund.org/grantdocuments/8INDM 16940 full.pdf & Indonesia \\
\hline http://www.theglobalfund.org/grantdocuments/8PRKM 17020 full.pdf & Korea \\
\hline http://www.theglobalfund.org/grantdocuments/8KGZM 17050 full.pdf & Kyrgyzstan \\
\hline http://www.theglobalfund.org/grantdocuments/8NGAM 17300 full.pdf & Nigeria \\
\hline http://www.theglobalfund.org/grantdocuments/8PNGM 17350 full.pdf & Papua New Guinea \\
\hline http://www.theglobalfund.org/grantdocuments/8RWNM 17440 full.pdf & Rwanda \\
\hline http://www.theglobalfund.org/grantdocuments/8SRLM 17560 full.pdf & Sri Lanka \\
\hline http://www.theglobalfund.org/grantdocuments/8SWZM 17590 full.pdf & Swaziland \\
\hline http://www.theglobalfund.org/grantdocuments/8TAJM 17630 full.pdf & Tajikistan \\
\hline
\end{tabular}


Table 1: Countries included in analyses by type of proposal (Continued)

\begin{tabular}{|c|c|}
\hline http://www.theglobalfund.org/grantdocuments/8TNZM 17660 full.pdf & Tanzania \\
\hline http://www.theglobalfund.org/grantdocuments/8UZBM 17740 full.pdf & Uzbekistan \\
\hline http://www.theglobalfund.org/grantdocuments/8ZANM 17820 full.pdf & Zanzibar \\
\hline http://www.theglobalfund.org/grantdocuments/8ZIMM 17850 full.pdf & Zimbabwe \\
\hline PMI Malaria Operational Plan & Country \\
\hline http://fightingmalaria.gov/countries/mops/fy09/angola mop-fy09.pdf & Angola \\
\hline http://fightingmalaria.gov/countries/mops/fy09/benin mop-fy09.pdf & Benin \\
\hline http://fightingmalaria.gov/countries/mops/fy09/ethiopia mop-fy09.pdf & Ethiopia \\
\hline http://fightingmalaria.gov/countries/mops/fy09/ghana mop-fy09.pdf & Ghana \\
\hline http://fightingmalaria.gov/countries/mops/fy09/kenya mop-fy09.pdf & Kenya \\
\hline http://fightingmalaria.gov/countries/mops/fy09/liberia mop-fy09.pdf & Liberia \\
\hline http://fightingmalaria.gov/countries/mops/fy09/madagascar mop-fy09.pdf & Madagascar \\
\hline http://fightingmalaria.gov/countries/mops/fy09/malawi mop-fy09.pdf & Malawi \\
\hline http://fightingmalaria.gov/countries/mops/fy09/mali mop-fy09.pdf & Mali \\
\hline http://fightingmalaria.gov/countries/mops/fy09/mozambique mop-fy09.pdf & Mozambique \\
\hline http://fightingmalaria.gov/countries/mops/fy09/rwanda mop-fy09.pdf & Rwanda \\
\hline http://fightingmalaria.gov/countries/mops/fy09/senegal mop-fy09.pdf & Senegal \\
\hline http://fightingmalaria.gov/countries/mops/fy09/tanzania mop-fy09.pdf & Tanzania \\
\hline http://fightingmalaria.gov/countries/mops/fy09/uganda mop-fy09.pdf & Uganda \\
\hline http://fightingmalaria.gov/countries/mops/fy09/zambia mop-fy09.pdf & Zambia \\
\hline
\end{tabular}

covigilance activities in any detail or request funds for pharmacovigilance in either PMI or Global Fund Round 8 proposal.

The frequency and amount of funding requested for pharmacovigilance by countries seeking funding for malaria programmes was also analysed. Seven of the 26 (27\%) Global Fund proposals included a request for funding for pharmacovigilance activities and seven of 15 (47\%)
MOPs included a request for funding for pharmacovigilance activities. Of the seven countries that requested funds for pharmacovigilance in their PMI MOPs for FY 2009 , two included pharmacovigilance within a line item with other treatment and training activities without separating out the component costs. Of the proposals that listed pharmacovigilance projects as an independent line item, the amount requested ranged from $\$ 50,000$ to 
Table 2: Pharmacovigilance mentions in PMI FY 2009 MOPs and in Global Fund Round 8 - Malaria proposals

\begin{tabular}{|c|c|c|c|c|}
\hline & $\begin{array}{l}\text { PMI FY } 2009 \text { Countries } \\
\text { (15 total) }\end{array}$ & $\begin{array}{l}\text { No. of responses } \\
\text { (\% of total) }\end{array}$ & $\begin{array}{l}\text { Global Fund Round } 8 \\
\text { Countries (26 total) }\end{array}$ & $\begin{array}{l}\text { No. of responses } \\
\text { (\% of total) }\end{array}$ \\
\hline \multicolumn{5}{|c|}{$\begin{array}{l}\text { Country has a Pharmacovigilance } \\
\text { Programme mentioned in MOP or } \\
\text { Global Fund proposal }\end{array}$} \\
\hline Yes & KEN, MDG, MWI, SEN, & $4(27 \%)$ & $\begin{array}{l}\text { BFA, CAF, COL, COM, CIV, } \\
\text { ETH, GHA, NGA, PNG, UZB, } \\
\text { ZBR, ZWE }\end{array}$ & $12(46 \%)$ \\
\hline No & AGO, ETH, GHA, LBR & $4(27 \%)$ & $\begin{array}{l}\text { AFG, BOL, BRA, COG, ECU, } \\
\text { COD, HTI, KGZ, RWA, TJK, } \\
\text { TZA, }\end{array}$ & $11(42 \%)$ \\
\hline Initial Phase of Development & BEN, MLI, MOZ, RWA, UGA & $5(33 \%)$ & & \\
\hline No mention in proposal & TZA, ZMB & $2(13 \%)$ & IDN, KOR, SWZ, & $3(12 \%)$ \\
\hline Total Respondents & & $15(100 \%)$ & & $26(100 \%)$ \\
\hline
\end{tabular}

\section{A section is dedicated to}

pharmacovigilance in the MOP or Global

Fund proposal

\begin{tabular}{llll}
\hline Yes & $\begin{array}{l}\text { LBR, MDG, MWI, MLI, MOZ, } \\
\text { RWA, SEN, UGA }\end{array}$ & COL, COM, COG, COD, ETH, 8 (31\%) \\
& & \\
\hline No & AGA, NGA, ZBR & \\
& TZA, ZMB & AFG, BOL, BRA, BFA, CAF, 18 (69\%) \\
& & CIV, ECU, HTI, IDN, KOR, \\
& KGZ, PNG, RWA, SWZ, TJK, \\
& TZA, UZB, ZWE
\end{tabular}

\begin{tabular}{lll}
\hline Total Respondents & $15(100 \%)$ & $26(100 \%)$
\end{tabular}

\section{A pregnancy registry is mentioned in the MOP or Global Fund proposal}

\begin{tabular}{|c|c|c|c|c|}
\hline Yes & UGA & $1(7 \%)$ & None & $0(0 \%)$ \\
\hline No/Not mentioned in proposal & $\begin{array}{l}\text { AGO, BEN, ETH, GHA, KEN, } \\
\text { LBR, MDG, MWI, MLI, MOZ, } \\
\text { RWA, SEN, TZA, ZMB }\end{array}$ & $14(93 \%)$ & All & $26(100 \%)$ \\
\hline Total Respondents & & $15(100 \%)$ & & $26(100 \%)$ \\
\hline
\end{tabular}

\footnotetext{
The country requested funds in its MOP

or Global Fund proposal for

pharmacovigilance activities:
}

\begin{tabular}{|c|c|c|c|c|}
\hline Yes & $\begin{array}{l}\text { GHA, MDG, MWI, MLI, } \\
\text { MOZ, RWA, UGA }\end{array}$ & 7 (47\%) & $\begin{array}{l}\text { CAF, COL, COG, CIV, NGA, } \\
\text { SWZ, ZBR }\end{array}$ & 7 (27\%) \\
\hline
\end{tabular}


Table 2: Pharmacovigilance mentions in PMI FY 2009 MOPs and in Global Fund Round 8 - Malaria proposals (Continued)

\begin{tabular}{|c|c|c|c|c|}
\hline No & $\begin{array}{l}\text { AGO, BEN, ETH, KEN, LBR, } \\
\text { SEN, TZA, ZMB }\end{array}$ & $8(53 \%)$ & $\begin{array}{l}\text { AFG, BOL, BRA, BFA, COM, } \\
\text { DR of Congo, ECU, ETH, } \\
\text { GHA, HTI, IDN, KOR, KGZ, } \\
\text { PNG, RWA, TJK, TZA, UZB, } \\
\text { ZWE }\end{array}$ & $19(73 \%)$ \\
\hline Total Respondents & & $15(100 \%)$ & & $26(100 \%)$ \\
\hline \multicolumn{5}{|c|}{$\begin{array}{l}\text { Type of Pharmacovigilance surveillance } \\
\text { mentioned in MOP or Global Fund } \\
\text { proposal }\end{array}$} \\
\hline Passive only & LBR, MWI, UGA & $3(20 \%)$ & $\begin{array}{l}\text { BFA, CAF, COL, COM, COG, } \\
\text { CIV, ETH, NGA, PNG, RWA, } \\
\text { UZB, ZBR, ZWE }\end{array}$ & $13(50 \%)$ \\
\hline Active only & & $0(0 \%)$ & & $0(0 \%)$ \\
\hline Both passive and active & MDG, MLI, RWA & $3(20 \%)$ & GHA & $1(4 \%)$ \\
\hline None mentioned & $\begin{array}{l}\text { AGO, BEN, ETH, GHA, KEN, } \\
\text { MOZ, SEN, TZA, ZMB }\end{array}$ & $9(60 \%)$ & $\begin{array}{l}\text { AFG, BOL, BRA, COD, ECU, } \\
\text { HTI, IDN, KOR, KGZ, SWZ, } \\
\text { TJK, TZA }\end{array}$ & $12(46 \%)$ \\
\hline
\end{tabular}

Total Respondents
A national agency in charge of
Pharmacovigilance activities is
mentioned in MOP or Global Fund
proposal

\begin{tabular}{|c|c|c|c|c|}
\hline Yes & $\begin{array}{l}\text { GHA, KEN, LBR, MDG, MWI, } \\
\text { MLI, MOZ, RWA, SEN, UGA, } \\
\text { ZMB }\end{array}$ & $11(73 \%)$ & $\begin{array}{l}\text { AFG, BOL, BRA, BFA, CAF, } \\
\text { COL, COM, COG, CIV, COD, } \\
\text { ETH, GHA, HTI, IDN, KOR, } \\
\text { KGZ, NGA, PNG, SWZ, TJK, } \\
\text { UZB, ZWE }\end{array}$ & $23(88 \%)$ \\
\hline No/Not mentioned in proposal & AGO, BEN, ETH, TZA & $4(27 \%)$ & ECU, RWA, TZA & $3(12 \%)$ \\
\hline Total Respondents & & $15(100 \%)$ & & $26(100 \%)$ \\
\hline
\end{tabular}

Afghanistan, AFG; Liberia, LBR; Angola, AGO; Angola, AGO; Madagascar, MDG; Benin, BEN; Malawi, MWl; Bolivia, BOL; Mali, MLl; Brazil, BRA; Mozambique, MOZ; Burkina Faso, BFA; Nigeria, NGA; Central African Republic, CAF; Papua New Guinea, PNG; Colombia, COL; Republic of Congo, COG; Cote D'Ivoire, CIV; Rwanda, RWA; Democratic Republic of Congo, COD; Senegal, SEN; Ecuador, ECU; Swaziland, SWZ; Ethiopia, ETH; Tajikistan, TJK; Ghana, GHA; Tanzania, TZA; Haiti, HTI; Uganda, UGA; Indonesia, IDN; Union of Comoros, COM; Kenya, KEN; Uzbekistan, UZB; Korea, KOR; Zambia, ZMB; Kyrgyzstan, KGZ; Zanzibar, ZBR

$\$ 700,000$ for activities over three years (Table 4). Analysing the amount requested for pharmacovigilance activities in the Global Fund proposals was not possible due to the manner in which the budgets are delineated; costs are grouped by type (human resources, supplies, etc.) rather than by activity.

\section{Discussion}

This study is, to the authors' knowledge, the first published systematic analysis of country-level pharmacovigilance activities and plans as contained in malaria control and prevention proposals submitted to two of the largest international donor groups. The findings show a lack of systematic and consistent inclusion of pharmacovigilance 
activities and requests for funding support in proposals and in country plans. This lack of consistency in what was defined and reported as pharmacovigilance across proposals demonstrates the need for stronger efforts to advance the role and effectiveness of the pharmacovigilance field to support malaria control and prevention programmes. The analysis also highlights the need for greater attention to pharmacovigilance in future proposals and country plans. Additionally, this analysis can serve as a baseline for assessing effectiveness of strategies to strengthen programmes over time.

This analysis, in light of the guidance from RBM issued in 2008, demonstrates that such a recommendation had been relatively ineffective and that more is needed to promote the inclusion of pharmacovigilance activities in funding proposals. Required inclusion of pharmacovigilance activities in drug procurement proposals and commensurate budget guidance should be explicitly stated in calls for applications. Recently, as part of the first phase of the Affordable Medicine Facility for malaria (AMFm) initiative, the World Health Organization (WHO) and the Medicines for Malaria Venture (MMV) developed a set of guidelines and recommendations for countries on how and what to include in pharmacovigilance sections of their AMFm proposals [19]. This publication is more detailed than the previous recommendation issued by RBM. Representatives from the Global Fund among other global health initiatives focused on malaria participated in the creation of this guidance, so the inclusion of pharmacovigilance activities should be a serious consideration of future Global Fund Technical Review Panels when evaluating proposals, including funding amounts requested. Future assessments will be needed to measure the impact of this guidance, including analyses of how funding has actually strengthened pharmacovigilance programmes. Budget estimation recommendations and links to potential technical assistance partners would make them even more useful and easily applicable. Delineating the operational details necessary for key methodologies such as active surveillance and stimulated spontaneous reporting could help countries, funders, and review panels develop the same vocabulary with which to describe and propose strengthening of pharmacovigilance structures.

Technical assistance to developing countries seeking to create or enhance their pharmacovigilance systems should be a streamlined, coordinated effort, and standardized reporting forms and mechanisms should be used as much as possible. Much of the infrastructure needed to support a functional pharmacovigilance system is the same as that needed for successful health informatics systems and epidemiologic surveillance. For programmes such as PMI, pharmacovigilance activities should be considered for integration into the current monitoring and evaluation plans, and could be used at the same sites that support sentinel health system or vector surveillance. Recognizing that the most effective pharmacovigilance system is one that is embedded within the health system and linked with the other functions of the existing structure, funders and implementing agencies should work collaboratively with other branches of the health system. This analysis serves as a starting point for future studies of pharmacovigilance activity levels globally. The data presented here serve as baseline indicators and should be tracked to measure the impact that recommendations such as those published by RBM and other future efforts to emphasize the importance of pharmacovigilance system strengthening have on their prominence in global health initiatives' agendas.

The lack of consistency in the descriptions of pharmacovigilance activities and proposed activities (see Additional file 1) underscores the need for coordinating funding streams and more specific strategies to assist in the supporting pharmacovigilance in low-income countries. RBM recommended that a national pharmacovigilance programme for anti-malarial drugs should cost between $\$ 150,000$ and $\$ 250,000$ USD for start-up with recurrent costs of around $\$ 50,000$ per year [20]. This amount would vary depending on the size of a country and the state of existing health infrastructure, such as laboratories, which are key components for pharmacovigilance, as well as other health system activities and the specific activities being proposed. Countries applying for Global Fund support can request support for pharmacovigilance activities under Health Systems Strengthening (HSS) Cross-Cutting Interventions, since a strong pharmacovigilance system is an integral part of a functioning national health system. Global health initiatives are now placing a renewed emphasis on HSS in their programming goals, providing an opportunity to include pharmacovigilance activities within this scope.

There were some limitations to this study. This analysis only presents a snapshot of pharmacovigilance plans and activities as reflected in country plans and key funding proposals for malaria control and prevention. As such, countries' existing pharmacovigilance capabilities and activities may not have been fully captured in this assessment. The budgets for pharmacovigilance in the Global Fund Round 8 proposals were not delineated in such a way as to identify how much funding was requested specifically for pharmacovigilance activities, so they cannot be analysed in the same way that the PMI MOPs can. Descriptions of pharmacovigilance activities and requests for pharmacovigilance support submitted to other funding sources were beyond the scope of this analysis. A brief assessment of the Country Operational Plans (COP) for 2009 submitted by countries that received support from the U.S. President's Emergency Plan for AIDS Relief 
Table 3: Comparison of four countries that submitted both GF Round 8 - Malaria and PMI 2009 proposals

\begin{tabular}{|c|c|c|c|c|c|c|c|c|}
\hline & \multicolumn{8}{|c|}{ Country } \\
\hline & \multicolumn{2}{|c|}{ Ghana } & \multicolumn{2}{|c|}{ Ethiopia } & \multicolumn{2}{|c|}{ Rwanda } & \multicolumn{2}{|c|}{ Tanzania } \\
\hline & $\begin{array}{l}\text { PMI FY } \\
2009 \text { MOP }\end{array}$ & $\begin{array}{l}\text { Global } \\
\text { Fund } \\
\text { Round } 8\end{array}$ & $\begin{array}{l}\text { PMI FY } \\
2009 \text { MOP }\end{array}$ & $\begin{array}{l}\text { Global } \\
\text { Fund } \\
\text { Round } 8\end{array}$ & $\begin{array}{l}\text { PMI FY } \\
2009 \text { MOP }\end{array}$ & $\begin{array}{l}\text { Global } \\
\text { Fund } \\
\text { Round } 8\end{array}$ & $\begin{array}{l}\text { PMI FY } \\
2009 \text { MOP }\end{array}$ & $\begin{array}{l}\text { Global } \\
\text { Fund } \\
\text { Round } 8\end{array}$ \\
\hline $\begin{array}{l}\text { Pharmacovigilance } \\
\text { programme } \\
\text { identified in country }\end{array}$ & No & Yes & No & Yes & $\begin{array}{l}\text { In initial } \\
\text { phase of } \\
\text { devel- } \\
\text { opment }\end{array}$ & No & $\begin{array}{l}\text { Not ment- } \\
\text { ioned }\end{array}$ & No \\
\hline $\begin{array}{l}\text { Section dedicated to } \\
\text { pharmacovigilance }\end{array}$ & No & Yes & No & Yes & Yes & Yes & No & Yes \\
\hline $\begin{array}{l}\text { Pregnancy registry } \\
\text { identified in country }\end{array}$ & No & No & No & No & No & No & No & No \\
\hline $\begin{array}{l}\text { Funds requested for } \\
\text { pharmacovigilance }\end{array}$ & Yes & No & No & No & Yes & No & No & No \\
\hline $\begin{array}{l}\text { Type of } \\
\text { pharmacovigilance } \\
\text { surveillance } \\
\text { activities mentioned } \\
\text { in the proposal }\end{array}$ & $\begin{array}{l}\text { Not ment- } \\
\text { ioned }\end{array}$ & $\begin{array}{l}\text { Passive and } \\
\text { active }\end{array}$ & $\begin{array}{l}\text { Not ment- } \\
\text { ioned }\end{array}$ & Passive & $\begin{array}{l}\text { Passive and } \\
\text { active }\end{array}$ & Passive & $\begin{array}{l}\text { Not ment- } \\
\text { ioned }\end{array}$ & $\begin{array}{l}\text { Not ment- } \\
\text { ioned }\end{array}$ \\
\hline $\begin{array}{l}\text { Agency identified in } \\
\text { charge of } \\
\text { pharmacovigilance } \\
\text { activities }\end{array}$ & Yes & Yes & No & Yes & Yes & No & No & No \\
\hline
\end{tabular}

(PEPFAR) found no mention of pharmacovigilance plans or budget requests in the COPs. Also, no information is presented here as to how the countries used the funds for pharmacovigilance activities as this was beyond the scope of this analysis.

In summary, the key finding from the analysis of both PMI MOPs from FY 2009 as well as GF Round 8 proposals was that overall, there is a dearth of requests for funding for pharmacovigilance programmes, despite acknowledgement by many in the global health community that pharmacovigilance is an integral component of any national malaria programme and health system as a whole. Even within the proposals that did include requests for funding pharmacovigilance programmes, the amounts were often less than recommended. These findings demonstrate the lack of emphasis placed on pharmacovigilance system strengthening despite the fact that in 2008 alone, 15.6 million treatment doses for ACT were procured through PMI in nine of its focus countries [21]. Additionally, it is evident from this analysis that the understanding of what defines a pharmacovigilance system and how much it should cost varies greatly between countries and their assistance partners who help prepare requests to their major donors. Both $\mathrm{WHO}$ and the Global Fund are developing a standard set of components needed for a basic functioning pharmacovigilance system. One indicator-based pharmacovigilance assessment tool has recently been developed and pilot tested through the Strengthening Pharmaceutical Systems programme [22]. Pharmacovigilance systems should improve when stakeholders collaborate on better defining and agreeing upon performance indicators and inform where important gaps exist, allowing for all concerned to contribute towards improving the safety of medicines. Investing in pharmacovigilance systems should not only benefit malaria control and prevention programmes, it should also ensure that robust surveillance, reporting and laboratory systems are in place for future monitoring of medications of all kinds. 
Table 4: Funding requests to PMI 2009 for pharmacovigilance activities

\begin{tabular}{ll}
\hline Country & $\begin{array}{l}\text { PMI 2009- amount } \\
\text { requested over } 3 \text { years }\end{array}$ \\
\hline Ghana & $\$ 110,000^{1}$ \\
\hline Madagascar & $\$ 100,000$ \\
\hline Malawi & $\$ 700,000$ \\
\hline Mali & $\$ 400,000$ \\
\hline Mozambique & $\$ 300,0001$ \\
\hline Rwanda & $\$ 112,100$ \\
\hline Uganda & $\$ 290,000$
\end{tabular}

${ }^{1}$ These figures come from budget line items that include, but are not exclusively pharmacovigilance activities.

\section{Conclusions}

Results from the analysis of both PMI MOPs from FY 2009 as well as GF Round 8 proposals indicate that the amount of money requested for pharmacovigilance activities in developing countries do not match up with largescale deployment of novel anti-malarial treatments and global acknowledgement that pharmacovigilance is an integral component of any national malaria programme and health system as a whole. Within the proposals that did include requests for funding pharmacovigilance programmes, it was difficult to tell what specifically the funds would be used for, and thus to know if sufficient amounts were being requested. For example, if a developing pharmacovigilance system would train and use existing staff to implement surveillance activities, the costs would be much lower than if new workers were necessary to implement the monitoring activities. Finally, there was considerable inconsistency in the pharmacovigilance elements described in requests to PMI and the Global Fund. The format of the proposals themselves, especially the layout of the Global Fund budgets make it difficult to know what specifically the funds will be used to do. Explicitly describing how funds will be used for specific pharmacovigilance activities will aid in achieving true transparency and improve the ability to monitor development of systems. All these findings demonstrate the lack of emphasis placed to-date on pharmacovigilance in recipient countries and among their funding and technical assistance partners as well as a lack of specificity about what the funds are being requested for. Enhanced global guidance and technical assistance could address these shortcomings and would support country and donor goals of ensuring access to high quality and safe treatments for malaria and other conditions. The inconsistencies in describing pharmacovigilance activities between the MOPs and GF proposals of countries that had both underscore the importance of providing welldefined expectations, standards, and tools for establishing and evaluating pharmacovigilance systems.

\section{Additional material}

Additional file 1 Description of proposed pharmacovigilance activi-

ties as excerpted from PMI MOPs for fiscal year 2009.

\section{Abbreviations}

ACT: artemisinin-based combination therapy; AMFm: Affordable Medicine Facility for malaria; COP: Country Operational Plan; KWIC: Key Word in Context; MMV: Medicines for Malaria Venture; MOP: Malaria Operational Plan; PEPFAR: U.S. President's Emergency Plan for AIDS Relief; PMI: President's Malaria Initiative; RBM: Roll Back Malaria; WHO: World Health Organization.

\section{Competing interests}

Jude Nwokike works for the Strengthening Pharmaceutical Systems Program, which receives funding from USAID and specifically from the President's Malaria Initiative.

\section{Authors' contributions}

AS devised the study design and objectives. AS and RJKB performed the data collection and analysis. All authors contributed to the interpretation of findings and drafting of the text and approved the final manuscript. The findings and conclusions presented in this paper are those of the authors. They do not represent the official position of CDC or the US Public Health Service.

\section{Acknowledgements}

Professor Stergachis acknowledges support from The Bill and Melinda Gates Foundation.

\section{Author Details}

1Department of Global Health, School of Public Health, Box 357236 University of Washington, Seattle, WA 98195, USA, 2Department of Epidemiology, School of Public Health, Box 357236 University of Washington, Seattle, WA 98195, USA , ${ }^{3}$ Centre for Tropical Clinical Pharmacology \& Therapeutics, University of Ghana Medical School, Korle-Bu Teaching Hospital, Accra, Ghana, ${ }^{4}$ Strengthening Pharmaceutical Systems, Center for Pharmaceutical Management, Management Sciences for Health, 4301 N. Fairfax Drive, Suite 400, Arlington, VA 22203, USA and 5 Malaria Branch, Division of Parasitic Diseases, Centers for Disease Control and Prevention, Atlanta, GA 30341, USA

Received: 19 February 2010 Accepted: 30 May 2010

Published: 30 May 2010

\section{References}

1. World Health Organization: 10 Facts on Malaria [http://www.who.int/ features/factfiles/malaria/en/index.html]. Accessed 21 November 2009

2. Roll Back Malaria Partnership: Global Malaria Action Plan [http:// www.rollbackmalaria.org/gmap/1-4.html]. Accessed 21 November 2009

3. World Health Organization: The new anti malaria drug policy for Ghana [http://www.who.int/countries/gha/news/2006/anti.malaria.drug.policy/ en/l. Accessed 21 November 2009

4. Dellicour S, Hall S, Chandramohan D, Greenwood B: The safety of artemisinins during pregnancy: a pressing question. Malar J 2007, 6:15.

5. Bate R, Coticelli P, Tren R, Attaran A: Antimalarial Drug Quality in the Most Severely Malarious Parts of Africa - A Six Country Study. PLOS ONE 2008, 3:e2132

6. Talisuna AO, Staedke SG, D'Alessandro U: Pharmacovigilance of antimalarial treatment in Africa: is it possible? Malar J 2006, 5:50. 
7. Pirmohammed M, Atuah KN, Dodoo ANO, Winstanley P: Pharmacovigilance in developing countries: Requires collaboration between stakeholders to develop novel models of funding. BMJ 2007, 335:462.

8. Strengthening Pharmaceutical Systems (SPS): Supporting pharmacovigilance in developing countries: the systems perspective. In Submitted to the U.S. Agency for International Development by the SPS Program Arlington, VA: Management Sciences for Health; 2009.

9. World Health Organization: The importance of pharmacovigilance. Geneva 2002.

10. Kennedy DL, Uhl K, Kweder SL: Pregnancy exposure registries. Drug Saf 2004, 27:215-228.

11. Guidance for industry: Establishing pregnancy exposure registries. US Food and Drug Administration. Center for Drug Evaluation and Research, Center for Biologics Evaluation and Research 2002 [http://www.fda.gov/ downloads/Drugs/GuidanceComplianceRegulatoryInformation/ Guidances/UCM071639.pdf]. Accessed 10 August 2008

12. European Medicine Agency: Guideline on the exposure to medicinal products during pregnancy: Need for post-authorisation data 2005 [http:// www.emea.europa.eu/pdfs/human/phvwp/31366605en.pdf]. Accessed 10 August 2008

13. World Health Organization: Assessment of the safety of artemisinin compounds in pregnancy. Report of two joint informal consultations convened in 20062007 [http://www.who.int/malaria/publications/atoz/ 9789241596114/en/]. Accessed 10 August 2008

14. Roll Back Malaria: Including pharmacovigilance in Global Fund's Round 8 Proposal 2008 [http://rbm.who.int/mmss/docs/Pharmacovigilancelntroen.pdf.

15. Roll Back Malaria: Steps for Completing Global Fund's Round 8 Proposal for Requesting funds for Pharmacovigilance 2008 [http:// www.rollbackmalaria.org/mmss/docs/ PharmacovigilanceFundingGFround8.pdf]. Accessed 21 November 2001

16. Bernard HR: Qualitative Data Analysis I: Text Analysis. In Research Methods in Anthropology: Qualitative and Quantitative Approaches 3rd edition. Chap 17, Walnut Creek: Altamira Press; 2002:440-488.

17. Richards L, Morse J: Readme first for a User's Guide to Qualitative Methods 2nd edition. Thousand Oaks: Sage Publications; 2007.

18. Muhr T: ATLAS.ti. Qualitative data analysis and visual model building in educational research. (Release 5.2)

19. Pharmacovigilance Guidance for Countries Participating in AMFm PHASE 1 WHO-MMV: Joint technical consultation on active pharmacovigilance monitoring with a special focus on AMFm. Geneva, Switzerland 2009.

20. Malaria Consortium - Roll Back Malaria: RBM Country Needs Assessment Template 2008 [http://www.rollbackmalaria.org/docs/rbmtoolbox/ Accessed 21 November 2009

21. Working with Communities to Save Lives in Africa: The President's Malaria Initiative Third Annual Report. Washington D.C 2009.

22. Strengthening Pharmaceutical Systems (SPS) Program: Indicator-Based Pharmacovigilance Assessment Tool: Manual for Conducting Assessments in Developing Countries. Submitted to the U.S. Agency for International Development by the SPS Program [http://pdf.usaid.gov/ pdf docs/PNADS167.pdf]. Arlington, VA: Management Sciences for Health, 2009 Accessed 15 May 2010

doi: $10.1186 / 1475-2875-9-148$

Cite this article as: Stergachis et al., A situational analysis of pharmacovigilance plans in the Global Fund Malaria and U.S. President's Malaria Initiative proposals Malaria Journal 2010, 9:148

\section{Submit your next manuscript to BioMed Centra} and take full advantage of:

- Convenient online submission

- Thorough peer review

- No space constraints or color figure charges

- Immediate publication on acceptance

- Inclusion in PubMed, CAS, Scopus and Google Scholar

- Research which is freely available for redistribution

Submit your manuscript at www.biomedcentral.com/submit
C Biomed Central 